Natural Hazards and Earth System Sciences, 5, 863-876, 2005

SRef-ID: 1684-9981/nhess/2005-5-863

European Geosciences Union

(C) 2005 Author(s). This work is licensed

under a Creative Commons License.

\title{
Validation of Digital Elevation Models around Merapi Volcano, Java, Indonesia
}

\author{
C. Gerstenecker ${ }^{1}$, G. Läufer ${ }^{1}$, D. Steineck ${ }^{2}$, C. Tiede $^{1}$, and B. Wrobel ${ }^{2}$ \\ ${ }^{1}$ Institute of Physical Geodesy, Darmstadt University of Technology, Darmstadt, Germany \\ ${ }^{2}$ Institute of Photogrammetry and Cartography, Darmstadt University of Technology, Darmstadt, Germany
}

Received: 8 October 2004 - Revised: 19 October 2005 - Accepted: 28 October 2005 - Published: 8 November 2005

\begin{abstract}
The accuracy of 4 Digital Elevation Models (SRTM30, GTOPO30, SRTM3 and local DEM produced from aerial photogrammetric images) for the volcanoes Merapi and Merbabu in Java, Indonesia is investigated by comparison with 443 GPS ground control points. The study confirms the high accuracy of SRTM3 and SRTM30, even if the a priori defined $90 \%$ confidence level of $16 \mathrm{~m}$ for the SRTM3 is not always achieved in this mountainous region. Accuracy of SRTM30, GTOPO30 and SRTM3 is mainly dependent on the altitude itself and the slopes' inclinations, whereas the photogrammetric DEM exhibits constant accuracy over a wide range of altitudes and slopes. For SRTM3 and SRTM30 a statistically significant correlation between heights and aspects of the slopes is also found.

Accuracy of DEMs which are generated by interpolation on a finer grid does not change significantly. Smoothing of DEMs on a coarser grid, however, decreases accuracy. The decrease in accuracy is again dependent on altitude and slope inclination.
\end{abstract}

The comparison of SRTM30 with GTOPO30 exhibits a significant improvement of SRTM30 data.

\section{Introduction}

Accurate and detailed knowledge of topography is basic to many earth processes in- and outside of its surface. Topographic information in the form of Digital Elevation Models (DEM) is used in Geosciences as a tool for reducing and explaining observations as well as for predicting and modeling possible natural hazards such as avalanches, landslides, rock falls or volcanic pyroclastic flows.

Between 1996 and 2002 we participated in the project "MERAPI" (Zschau et al., 1998). One of the most active volcanoes in the world - Merapi in Central Java, Indonesia - was

Correspondence to: C. Gerstenecker

(gerstenecker@geod.tu-darmstadt.de) investigated in order to learn how this volcano works and to increase the possibilities of correctly predicting its volcanic activities. In the beginning we immediately realized there was a lack of accurate, up-to-date topographic data. We had available - for our purposes very coarse - the GTOPO30DEM, bad copies of old topographic maps from 1948, scale 1:25000 and SPOT images.

A DEM was developed from the SPOT images with a grid size of $20 \times 20 \mathrm{~m}$. However, it has large data gaps due to clouds and smoke development, especially around the summits of Merapi and Merbabu. These gaps were filled by interpolation and merging of the digitized contour lines of the topographic maps (Jousset, 1996). Standard deviation - determined by comparison with the heights of 360 ground control points - is $121 \mathrm{~m}$ (Snitil, 1998).

To improve the situation concerning accuracy and resolution we developed a local DEM - called "LDEM" - from aerial photogrammetric images.

In November 2003 the SRTM3 and SRTM30 DEMs for Europe and Asia were released. We have now the possibility of comparing different DEMs around Merapi to assess accuracy and resolution of DEMs in tropic mountainous regions. In the following sections we will give more detailed information about the region under investigation, the DEMs used in this study, the applied statistics, results of the comparisons carried out and final conclusions.

\section{The region around Merapi and Merbabu}

The andesitic stratovolcano Merapi in Central Java, Indonesia (latitude $=7^{\circ} 32^{\prime} 26^{\prime \prime} \mathrm{S}$, longitude $=110^{\circ} 26^{\prime} 48^{\prime \prime} \mathrm{E}$, altitude $=2950 \mathrm{~m}$ above sea level (a.s.1.)), is one of the most active volcanoes in the world. It is located near the subduction zone of the Indo-Australian plate under the Eurasian plate (Fig. 1a) at the Sunda Arc. Merapi is the youngest of a chain of volcanoes lined up along a regional fault running NNW-SSE and consisting of Ungaran, Telomoyo, Merbabu and Merapi (van Bemmelen, 1956) (Fig. 1b). 


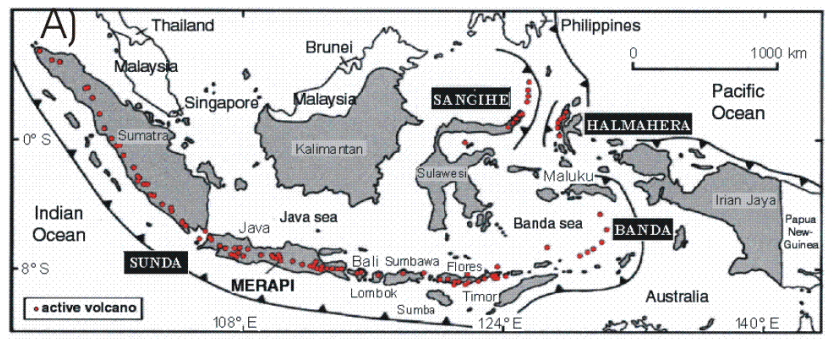

B)

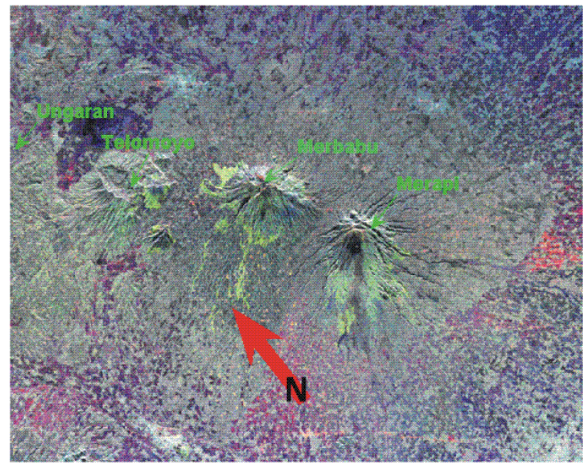

Fig. 1. Location of the volcanoes Merapi and Merbabu. (a) Map of Indonesia; the red points indicate the locations of active volcanoes. (b) SIR-C/X-SAR- satellite image P-4750 of Central Java taken on October 10, 1994. The volcanoes Ungaran, Telomoyo, Merbabu and Merapi are lined up along a regional fault running NNW-SSE.

The volcanic activities of Merapi are classified as follows:

- permanent lava dome development

- periodic dome collapses connected with pyroclastic flows

- lahars at the slopes, especially at the beginning of the rainy season.

The Volcanological Survey of Indonesia (VSI) permanently monitors Merapi's activities in 5 observatories (Fig. 2).

The region around Merapi and Merbabu is densely populated. Volcanic eruptions of Merapi threaten the city of Yogyakarta, located $25 \mathrm{~km}$ to the south. Two million people live in and near the so-called forbidden, first and second danger zones.

The elevation range of the region is sizable. Yogyakarta is located at a mean altitude of $100 \mathrm{~m}$ a.s.l. The summit of Merbabu is higher than $3100 \mathrm{~m}$ a.s.l.

The surface relief around Merapi and Merbabu is very rough. We have analyzed the relief roughness in a region of about $37 \mathrm{~km} \times 26 \mathrm{~km}$ around Merapi and Merbabu using the relief roughness coefficient RR of Meybeck et al. (2001)

$R R=\frac{h_{\max }-h_{\min }}{c s / 2}$

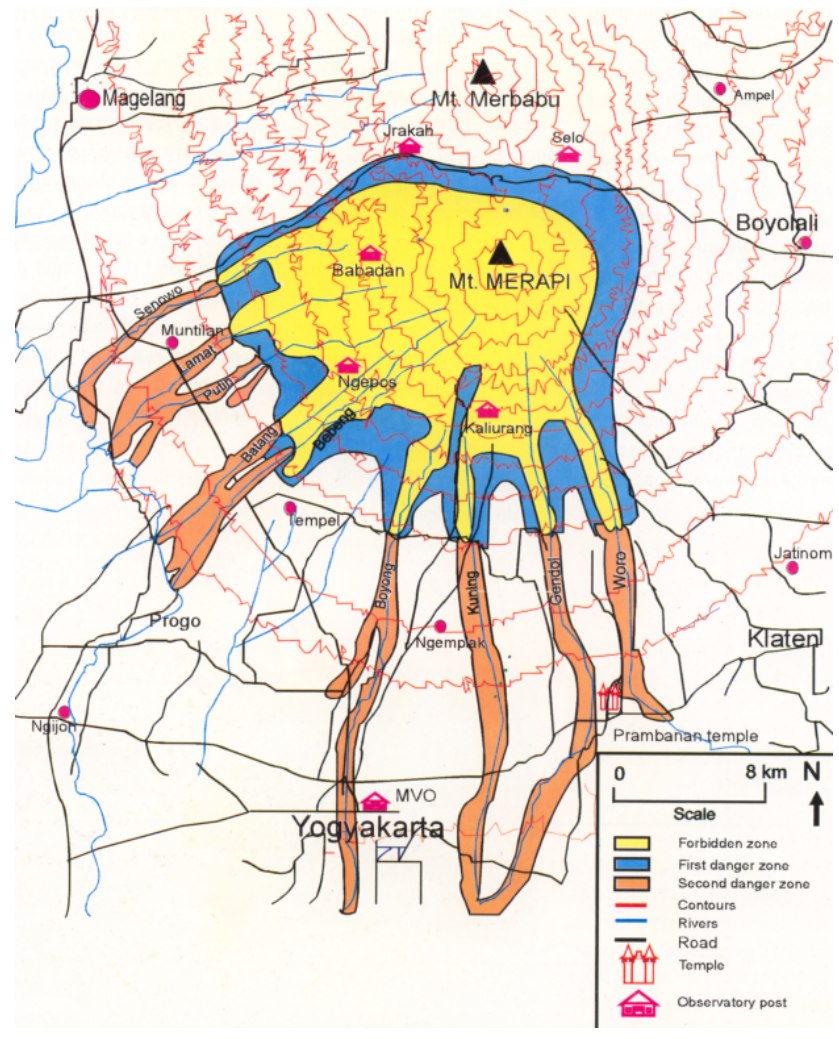

Fig. 2. Hazard map of Merapi according to Purbawinata et al. (1996).

Table 1. Relief Roughness RR around Merapi and Merbabu; cell size $=3 \times 3^{\prime \prime}$. The computation is based on the SRTM3 - Digital Elevation Model.

\begin{tabular}{cccc}
\hline $\mathrm{RR}(\mathrm{m} / \mathrm{km})$ & Cells & Cells $(\%)$ & Area $\left(\mathrm{km}^{2}\right)$ \\
\hline $\mathrm{RR}<250$ & 24471 & 20 & 198.215 \\
$250 \leq \mathrm{RR}<500$ & 52254 & 43 & 432.257 \\
$500 \leq \mathrm{RR}<750$ & 15725 & 13 & 127.372 \\
$750 \leq \mathrm{RR}$ & 28146 & 24 & 227.982 \\
Total & 120596 & 100 & 976.827 \\
\hline
\end{tabular}

with cs length of cell in kilometers $=0.092 \mathrm{~km}, h_{\max }, h_{\min }$ maximal and minimal elevation in the cell in meters. For the analysis we used the SRTM3 DEM as described in Sect. 3.1.2.

Inspection of Table 1 shows that relief roughness coefficients RR of $80 \%$ of cells are $\geq 250(\mathrm{~m} / \mathrm{km})$. Classification of the topography according to Meybeck et al. (2001) is not meaningful, since more than $80 \%$ of the cells are classified as "mountainous, very rough".

The maximal slope angle reaches $50^{\circ}$.

Up to $1800 \mathrm{~m}$ a.s.l. agricultural use of the land around Merapi and Merbabu prevails. But dense tropical rain forests can also be found - particularly on the eastern and southern slopes of Merapi and Merbabu. At altitudes between $1800 \mathrm{~m}$ 
and $2600 \mathrm{~m}$ vegetation consists of grasses and bushes. Above $2600 \mathrm{~m}$ a.s.l. rocks and gravels prevail.

In the following sections we will analyze the accuracy of DEMs between $7^{\circ}-8^{\circ} \mathrm{S}$ and $110^{\circ}-111^{\circ} \mathrm{E}$. Our particular interest is focused on a region around Merapi and Merbabu extending $37 \mathrm{~km}$ in N-S direction and $26 \mathrm{~km}$ in E-W direction.

\section{Data}

\subsection{Digital Elevation Models}

In this study we compare 4 of the DEMs currently available for the region around Merapi and Merbabu:

$$
\begin{aligned}
& \text { - LDEM } \\
& \text { - SRTM3 } \\
& \text { - SRTM30 } \\
& \text { - GTOPO30 }
\end{aligned}
$$

\subsubsection{Local Digital Elevation Model LDEM}

The local Digital Elevation Model LDEM is a digital surface model (DSM), which we have developed from 110 aerial images, image scale 1:50000. The images were taken in 1981 and 1982. The camera constant is $88 \mathrm{~mm}$, average flight height $5600 \mathrm{~m}$ a.s.l.; image overlap along the track of flight is $60 \%$, side lap $20 \%$. The orientation of the images was achieved with the bundle solution using automatic tied point generation and a subset of ground control points (GCPs) (see Sect. 3.2). Grid spacing is $0.5 \times 0.5^{\prime \prime}$. LDEM is located between $7^{\circ} 20^{\prime} 18^{\prime \prime}-7^{\circ} 40^{\prime} 54^{\prime \prime} \mathrm{S}$ and $110^{\circ} 17^{\prime} 48^{\prime \prime}-$ $110^{\circ} 32^{\prime} 21^{\prime \prime} \mathrm{E}$ and covers an area of $37 \mathrm{~km} \times 26 \mathrm{~km}$ around Merapi and Merbabu.

Elevations of LDEM are ellipsoidal heights $\mathrm{H}$ referenced to the WGS84 ellipsoid (Fig. 3a).

The standard deviation of image coordinates \pm 0.45 pixel as obtained by bundle solution corresponds to $\pm 9 \mathrm{~m}$ in elevation. That coincides with the anticipated accuracy of LDEM $\sigma_{h} \leq \pm 8.7 \mathrm{~m}$ according to Eq. (2) (Kraus, 2004).

$\sigma_{h} \leq \pm 0.0002 * h+\frac{0.0001}{c} h * \tan \alpha$,

where $c$ is camera constant, $h$ flight height above surface $\leq 5600 \mathrm{~m}$ and $\alpha$ slope angle $\leq 50^{\circ}$. Assuming no systematic errors and normal distribution of the residuals, the a priori accuracy of LDEM is $14.3 \mathrm{~m}$ at the $90 \%$ confidence interval (Sachs, 1992) according to Eq. (6).

More details about developing LDEM are given by Wrobel et al. (2002) and Läufer (2003).

The LDEM-data were also averaged $6 \times 6$ to produce 3 arc second data commensurate with SRTM33 (see Sect. 3.1.2). This DEM is referred to as "LDEM33".
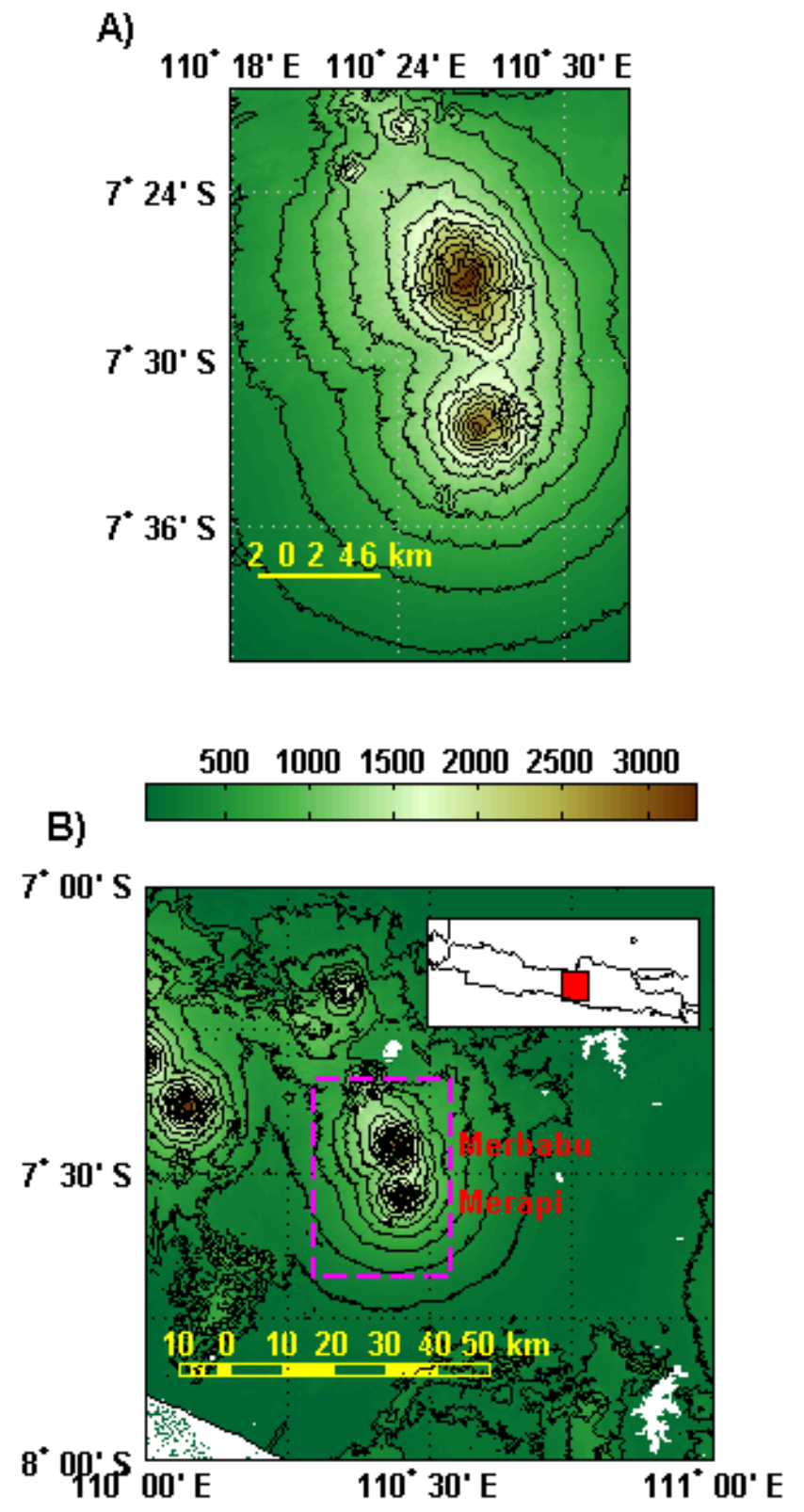

Fig. 3. Local photogrammetric DEM and SRTM3 DEM around Merapi and Merbabu. The color bar gives elevation above sea level (a.s.1.) in meters. Contour line interval is $200 \mathrm{~m}$. (a) Local photogrammetric DEM "LDEM". (b) SRTM3-DEM; the red rectangle in the inset map of Java is the section represented. The magenta dashed rectangle indicates the regions of other DEMs e.g. LDEM, LDEM33, SRTM33 and SRTM0505.

\subsubsection{SRTM3}

The Shuttle Radar Topography Mission (SRTM) is a joint venture of NASA's Jet Propulsion Laboratory, National Imaging \& Mapping Agency (NIMA), and the German (DLR) and Italian Space Agencies (ASI).

From 11-22 February 2000, the Shuttle Radar Topography Mission (SRTM) was flown on board the space shuttle "Endeavour" (Koch and Heipke, 2001). SRTM utilized 


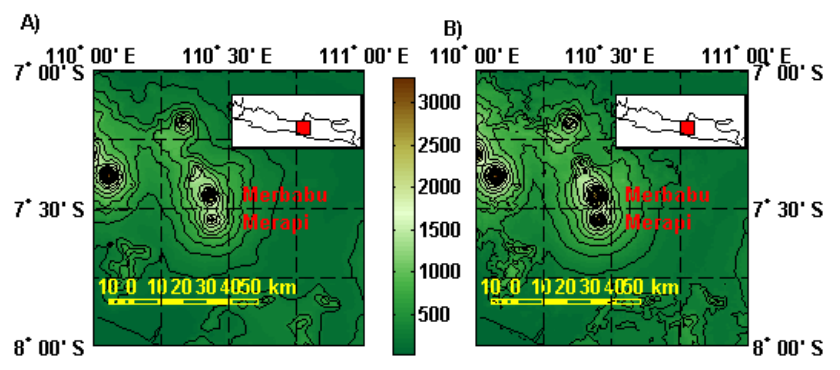

C)

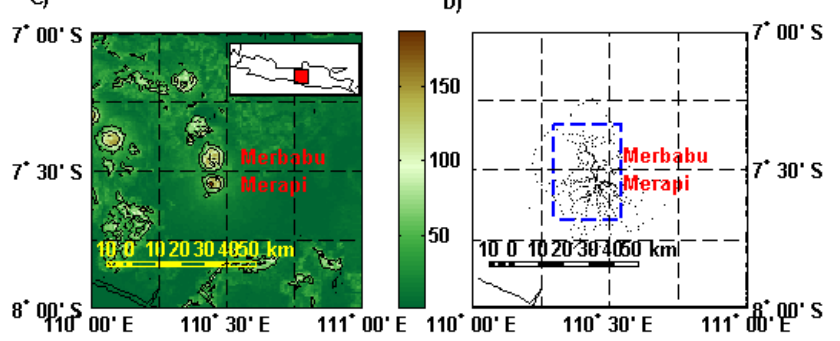

Fig. 4. GTOPO30 and SRTM 30 DEMs of Central Java; the red rectangle in the inlet maps of Java gives the range of the DEMs shown; contour line interval is $200 \mathrm{~m}$, unless otherwise noted. (a) GTOPO30 DEM; (b) SRTM30 DEM; (c) Standard deviations of SRTM30 heights of Central Java; contour line interval is $50 \mathrm{~m}$; (d) Ground Control Points GCPs used to determine absolute accuracy of DEMs. The blue dashed rectangle describes the range of the local LDEM.

dual Spaceborne Imaging Radar (SIR-C) and dual X-band Synthetic Aperture Radar (X-SAR) configured as a baseline interferometer (Rosen et al., 2000), acquiring two images simultaneously. These images, when combined, can produce a single 3-D image. SRTM successfully collected data for $80 \%$ of the earth's land surface, for most of the area between $60^{\circ} \mathrm{N}$ and $56^{\circ} \mathrm{S}$ latitude (Farr and Kobrick, 2000). SRTM data is being used to generate a digital topographic map of the Earth's land surface with data points spaced every 1 arc second for the United States of America (SRTM1) and 3 arc seconds for global coverage (SRTM3) of latitude and longitude. The linear absolute vertical accuracy is $16 \mathrm{~m}$, the horizontal circular error $20 \mathrm{~m}$ at the $90 \%$ confidence level (http://www.nga.mil/ast/fm/acq/890208.pdf MIL-PRF-89020B).

Since November 2003 unedited SRTM3 data have been available under ftp://e0mss21u.ecs.nasa.gov/srtm/. In July 2004 the release was completed with the data of Australia. All this data is specified as being of "research grade". The data does not meet DTED standards (NIMA, 2000) and has not been edited for voids and spurious height values. Water bodies often have spurious appearance. In the meantime, "completed" SRTM-Digital Terrain Elevation Data (SRTM DTED) have also been made available on CD at a cost of $60 \$ / C D$. A complete overview of all available data can be found at Gamache (2004).

Figure $3 \mathrm{~b}$ shows the unedited SRTM3-DEM for Central Java between $7^{\circ}-8^{\circ} \mathrm{S}$ and $110^{\circ}-111^{\circ} \mathrm{E}$. The white areas are due to the data gaps. No data exist for 19950 cells or $1.4 \%$ of the area. Also some cells of the Indian Ocean in the NW corner are not set to $0 \mathrm{~m}$.

Generally any SRTM-DEM is a Digital Surface Model (DSM). That means, the elevation data are with respect to the reflective surface, which may be vegetation, man-made features or bare earth. The elevations $h$ are given above the WGS84 geoid (a.s.1.).

The SRTM dataset, like many other global datasets, has accuracy parameters, which describe it globally, while specific elevation errors are not sufficiently defined.

The C band Interferometric Synthetic Aperture Radar (InSAR) instrument utilized to collect SRTM data had an incidence angle of between $31^{\circ}$ and $61^{\circ}$ thus resulting in slopes of corresponding angles being difficult to image accurately. Mountainous regions such as Merapi and Merbabu are particularly prone to different types of errors with InSAR systems: Layover, shadowing, foreshortening and voids when the slope angle exceeds the incidence of the radar beam (Hansen, 2001; Läufer, 2003; Eineder, 2004).

Different validation studies of the SRTM data have been published (see e.g. Heipke et al., 2002; Sarabandi et al., 2002; Smith and Sandwell, 2003; Jarvis et al., 2004a, b; Kocak et al., 2004; Falorni et al., 2005) investigating the specific accuracy of SRTM-DEMs.

Generally all authors find that SRTM3 DEMs meet the anticipated accuracies of $16 \mathrm{~m}$ vertical and $20 \mathrm{~m}$ horizontal accuracy over flat, open land surfaces. Over terrain with high relief and steep slopes, however, Falorni et al. (2005) suggest that the $16 \mathrm{~m}$ stated accuracy specifications should be considered more as guidelines. Gamache (2004) provides a good review of most of the studies. However, no study investigates the accuracy of SRTM3 in mountainous, tropic regions over an elevation range of about $3000 \mathrm{~m}$ as we do in this work.

We have derived 3 different DEMs from the original SRTM3 DEM:

- SRTM3F for Central Java between $7^{\circ}-8^{\circ} \mathrm{S}$ and $110^{\circ}-$ $111^{\circ} \mathrm{E}$ is a DEM with $3 \times 3^{\prime \prime}$ grid spacing where the voids are filled by interpolation using the shareware software "SRTMFILL" (3D Nature, 2003).

- SRTM33 is a subset of SRTM3F for the same range as LDEM. Grid size is $3 \times 3^{\prime \prime}$.

- SRTM0505 has the same range and grid size $\left(0.5 \times 0.5^{\prime \prime}\right)$ as LDEM. It is computed by bilinear interpolation of SRTM33 data.

\subsubsection{GTOPO30}

GTOPO30, completed in late 1996, was developed over a three year period. It is essentially a compilation of various elevation data sources and samples the global topography on a grid size of $30 \times 30^{\prime \prime}$. In Java only data from Digital Chart of the World (DCW) (Danko, 1992) are used. There are no data gaps. 
Table 2. Summary of the DEMs analysed. * Voids are not considered.

\begin{tabular}{|c|c|c|c|c|c|}
\hline Dataset & $\begin{array}{c}\text { Grid } \\
\text { spacing }\end{array}$ & Region & $\begin{array}{c}\text { Epoch of } \\
\text { generation (year) }\end{array}$ & $\begin{array}{c}\text { number of } \\
\text { cells }\end{array}$ & $\begin{array}{c}\text { accuracy }(90 \% \\
\text { confidence level (m) }\end{array}$ \\
\hline GTOPO30 & $30 \times 30^{\prime \prime}$ & $\begin{array}{c}8-7^{\circ} \mathrm{S} \\
110^{\circ}-111^{\circ} \mathrm{E}\end{array}$ & before 1996 & 14400 & 160 \\
\hline SRTM30 & $30 \times 30^{\prime \prime}$ & $\begin{array}{c}8-7^{\circ} \mathrm{S} \\
110^{\circ}-111^{\circ} \mathrm{E}\end{array}$ & 2000 & 14400 & $<302$ \\
\hline SRTM3 & $3 \times 3^{\prime \prime}$ & $\begin{array}{c}8-7^{\circ} \mathrm{S} \\
110^{\circ}-111^{\circ} \mathrm{E}\end{array}$ & 2000 & $1422451^{*}$ & 16 \\
\hline SRTM3F & $3 \times 3^{\prime \prime}$ & $\begin{array}{c}8-7^{\circ} \mathrm{S} \\
110^{\circ}-111^{\circ} \mathrm{E}\end{array}$ & 2000 & 1442401 & 16 \\
\hline SRTM33 & $3 \times 3^{\prime \prime}$ & $\begin{array}{c}7^{\circ} 41^{\prime}-7^{\circ} 20^{\prime} \mathrm{S} \\
110^{\circ} 18^{\prime}-110^{\circ} 32^{\prime} \mathrm{E}\end{array}$ & 2000 & 120598 & 16 \\
\hline SRTM0505 & $0.5 \times 0.5^{\prime \prime}$ & $\begin{array}{c}7^{\circ} 41^{\prime}-7^{\circ} 20^{\prime} \mathrm{S} \\
110^{\circ} 18^{\prime}-110^{\circ} 32^{\prime} \mathrm{E}\end{array}$ & 2000 & 4347440 & 16 \\
\hline LDEM & $0.5 \times 0.5^{\prime \prime}$ & $\begin{array}{c}7^{\circ} 41^{\prime}-7^{\circ} 20^{\prime} \mathrm{S} \\
110^{\circ} 18^{\prime}-110^{\circ} 32^{\prime} \mathrm{E}\end{array}$ & $1981 / 1982$ & 4347440 & $\leq 14.7$ \\
\hline LDEM33 & $3 \times 3^{\prime \prime}$ & $\begin{array}{c}7^{\circ} 41^{\prime}-7^{\circ} 20^{\prime} \mathrm{S} \\
110^{\circ} 18^{\prime}-110^{\circ} 32^{\prime} \mathrm{E}\end{array}$ & $1981 / 1982$ & 120598 & $\leq 14.7$ \\
\hline
\end{tabular}

The circular accuracy in the DCW is stated as $\pm 650 \mathrm{~m}$ at the $90 \%$ confidence level (USGS-EROS Data Center, 1997), although Gesch et al. (1999) suggest that 160 m linear vertical error is more realistic based on comparison with higher resolution sources.

In the following we will analyze only a section of GTOPO30 between $7^{\circ}-8^{\circ} \mathrm{S}$ and $110^{\circ}-111^{\circ} \mathrm{E}$ (Fig. 4a).

\subsubsection{SRTM30}

SRTM30 (Fig. 4b) can be considered to be either a SRTM dataset enhanced with GTOPO30, or an upgrade to GTOPO30. The SRTM3 data were averaged $10 \times 10$ to produce 30 arc second data commensurate with GTOPO30. SRTM30 data can be downloaded at no cost from ftp:// e0mss21u.ecs.nasa.gov/srtm/. Instead of a $90 \%$ confidence level, the standard deviation of each cell is provided. Figure 4c shows the SRTM30 standard deviations for Central Java between $7^{\circ}-8^{\circ} \mathrm{S}$ and $110^{\circ}-111^{\circ} \mathrm{E}$. The maximum standard deviation is $189 \mathrm{~m}$.

Standard deviations of cells of altitudes $<500 \mathrm{~m}$ are $< \pm 20 \mathrm{~m}$. The largest standard deviations are found at the summits of volcanoes e.g. Merapi and Merbabu.

\subsection{Ground control points}

Between 1996 and 2002 we carried out repeated gravity measurements around Merapi and Merbabu (Gerstenecker et al., 1998; Setiawan, 2003; Tiampo et al., 2004; Jentzsch et al., 2004; Tiede et al., 2005). For the positioning of gravity points geodetic Trimble and Leica GPS receivers were utilized. Least square adjustments of the GPS-observations with the software packages GPSurvey 3.5 (Division, 1995) and "Bernese 4.2" (Hugentobler et al., 2001) yield identical results. The root mean square errors (RMSE) for the horizon- tal coordinates are $< \pm 0.1 \mathrm{~m}$ and for the vertical $< \pm 0.2 \mathrm{~m}$ (Götz, 2003). Horizontal accuracy at the $90 \%$ confidence level is $0.16 \mathrm{~m}$, the vertical $0.32 \mathrm{~m}$.

In total we have determined the 3-D coordinates of 443 points in the International Terrestrial Reference Frame 2000 (Boucher et al., 2004). We use them in the following as Ground Control Points (GCPs) (Fig. 4d).

The coordinates of the GCPs are given on the WGS84 ellipsoid. The elevations $\mathrm{H}$ are ground truth ellipsoidal heights. In order to convert them to heights $h$ above sea level (a.s.1.) the geoid heights $\mathrm{N}$ are subtracted according to Eq. (3) (Heiskanen and Moritz, 1967)

$h=H-N$.

Global geoid heights with $2 \times 2^{\prime}$ grid spacing calculated from the Earth Gravity Model 96 (EGM96) (Lemoine et al., 1997) are currently available from http://topex.ucsd.edu/ cgi-bin/get_data.cgi.

Table 2 provides a summary of the data described in Sect. 3. One important criterion for the following investigation is the period in which the data of the DEMs are collected. Changes in geomorphology and vegetation in tropic, volcanic regions occur very quickly and have to be considered if different DEMs in such regions are compared.

\section{Statistics}

The most general approach to assess the accuracy of DEMs is the application of frequency analysis as described by Kraus (2000). More convenient, however, is to validate DEMs in the space domain. In particular the absolute accuracy of DEMs is assessed by comparison with GCPs that have, to some degree, higher vertical accuracy and/or by compari- 
Table 3. Statistics for the different DEMs; $n=$ number of available ground control points $(\mathrm{GCP})$; $i q r=$ interquartile range. Extreme values are marked by bold numbers.

\begin{tabular}{|c|c|c|c|c|c|c|c|c|}
\hline DEM & $n$ & bias $h_{\text {off }}(\mathrm{m})$ & median $(\mathrm{m})$ & standard deviation $\sigma_{d}(\mathrm{~m})$ & skewness $\gamma_{d}$ & kurtosis $\kappa_{d}$ & range $(\mathrm{m})$ & $i q r(\mathrm{~m})$ \\
\hline SRTM3 & 443 & -0.2 & 3.1 & 13.4 & -0.9 & 10.4 & 145 & 8.2 \\
\hline SRTM3F & 443 & -0.2 & 3.1 & 13.4 & -0.9 & 10.4 & 145 & 8.2 \\
\hline SRTM33 & 347 & -1.4 & 2.2 & 14.7 & -0.9 & 8.7 & 145 & 11.3 \\
\hline SRTM0505 & 347 & -1.3 & 2.4 & 13.9 & -0.6 & 6.8 & 114 & 11.2 \\
\hline LDEM & 347 & 8.3 & 9.4 & 14.9 & -1.9 & 31.7 & 234 & 11.8 \\
\hline LDEM33 & 347 & 4.5 & 5.3 & 15.9 & -0.8 & 13.8 & 199 & 15.7 \\
\hline SRTM30 & 443 & -14 & 0.3 & 68.8 & -1.4 & 7.8 & 595 & 37.7 \\
\hline GTOPO30 & 443 & -102.5 & -38.5 & 249.2 & -2.0 & 7.3 & 1580 & 166 \\
\hline
\end{tabular}

son with other DEMs of higher accuracy (Koch and Heipke, 2001; Muller et al., 2000; Jarvis et al., 2004a, b).

Relative accuracy of a DEM is assessed by comparing it with a reference DEM of the same extension and grid size.

To estimate absolute accuracy, elevations $h_{\mathrm{DEM}}$ at the locations of GCPs were extracted from all DEMs and compared with the elevations of GCPs $h_{\mathrm{GCP}}$ in order to determine the differences $d_{i}$, bias $h_{\text {off }}$, residuals $v_{i}$, standard deviation $\sigma_{d}$, skewness $\gamma_{d}$, kurtosis $\kappa_{d}$ and range according to Eq. (4)

$$
\begin{aligned}
& d_{i}=h_{\mathrm{DEM}}-h_{\mathrm{GCP}} \\
& h_{\mathrm{off}}=\frac{1}{n} \sum_{i=1}^{n} d_{i} \\
& v_{i}=d_{i}-h_{\mathrm{off}} \\
& \sigma_{d}=\sqrt{\frac{\sum_{i=1}^{n} v_{i}^{2}}{n-1}} \\
& \gamma_{d}=\frac{E\left[v_{i}^{3}\right]}{\sigma_{d}^{3}} \\
& \kappa_{d}=\frac{E\left[v_{i}^{4}\right]}{\sigma_{d}^{4}} \\
& \text { range }=v_{\max }-v_{\min }
\end{aligned}
$$

where $n$ is number of samples and $E$ mathematical expectation. Additionally we give the median (50th percentile) of the differences $d_{i}$ and the interquartile range $i q r$ - the difference between the 75 th and 25 th percentile of the residuals $v_{i}$. Scatter plots of $v_{i}$ over $h_{\mathrm{GCP}}$ represent the dependence of residuals $v_{i}$ from elevations $h_{\mathrm{GCP}}$. Histograms show the distribution of residuals $v_{i}$ of the particular DEMs.

Residuals $v_{i}$ of all DEMs are binned into different classes depending on height $h_{\mathrm{GCP}}$, slope $\alpha_{\mathrm{GCP}}$ and aspect $A_{\mathrm{GCP}}$ at GCP locations. Biases and standard deviations for each class are computed and plotted against $h_{\mathrm{GCP}}$, slope $\alpha_{\mathrm{GCP}}$ and aspect $A_{\mathrm{GCP}}$, respectively.

The relative accuracy between two Digital Elevation Models $\mathrm{DEM}_{1}$ and $\mathrm{DEM}_{2}$ of identical grid size is evaluated in a similar way. Instead of $h_{\mathrm{GCP}}$, the heights of a second DEM $h_{\text {DEM2 }}$ are used as reference. The differences $d r_{i}$ of the heights $h, d A_{i}$ of the aspects $A$ and $d \alpha_{i}$ of the slopes $\alpha$, respectively, are computed using Eq. (5).

$$
\begin{aligned}
& d r_{i}=h_{\mathrm{DEM} 1}-h_{\mathrm{DEM} 2} \\
& d A_{i}=A_{\mathrm{DEM} 1}-A_{\mathrm{DEM} 2} \\
& d \alpha_{i}=\alpha_{\mathrm{DEM} 1}-\alpha_{\mathrm{DEM} 2}
\end{aligned}
$$

Bias $h_{\text {off }}$, residuals $v_{i}$, standard deviation $\sigma_{d}$, skewness $\gamma_{d}$ and kurtosis $\kappa_{d}$ are estimated by inserting the differences $d r_{i}$, $d A_{i}$ and $d \alpha_{i}$ instead of $d_{i}$ in Eq. (4).

Residuals $v_{i}$ are binned again in different classes dependent on height $h_{\mathrm{DEM} 2}$, slope $\alpha_{\mathrm{DEM} 2}$ and aspect $A_{\mathrm{DEM} 2}$.

\section{Results}

5.1 Absolute accuracy of DEMs from ground control points

Elevation values were extracted from all DEMs and compared with the GCPs-heights in order to determine the parameters according to Eq. (4). The results of the comparison are summarized in Table 3.

Inspection of Table 3 shows that the interpolation of gaps in SRTM3 does not influence the absolute accuracy. Therefore, in the following we provide results only for SRTM3F and all offsprings, e.g. SRTM33 and SRTM0505.

The residuals $v_{i}$ of the DEMs do not have a normal distribution, since skewness $\gamma_{d}$ is always $\neq 0$. Some of the distribution histograms are plotted as examples in Fig. 5a-5d.

In the literature there are no hints indicating for which distribution the $90 \%$ confidence level of SRTM3 is defined. If we assume normal distribution, the $90 \%$ confidence level is related to the standard deviation $\sigma_{d}$ according to Eq. (6) (Sachs, 1992)

$P\left(\left|v_{i}\right| \geq 1.645 \sigma_{d}\right) \leq 0.1$.

The a priori standard deviation $\sigma_{d}$ of SRTM3 is then $\leq 10 \mathrm{~m}$.

Otherwise Tschebyscheff's inequality

$P\left(\left|v_{i}\right| \geq k \sigma_{d}\right) \leq \frac{1}{k^{2}}$

with $k=3$ is valid. We present, therefore, in Table 4 the number of samples for 4 different error margins 
Table 4. Number of samples $v_{i}$ within different error bounds. $N$ is the number of all available GCPs (100\%), $n$ the number of samples, where $v_{i}$ is within the error margins. Extreme values are marked by bold numbers. ${ }^{+}$For SRTM30 and GTOPO30 a $90 \%$ confidence interval $-160 \mathrm{~m} \leq \sigma \leq 160 \mathrm{~m}$ is assumed.

\begin{tabular}{lccccccccc}
\hline DEM & \multicolumn{3}{c}{$-\sigma_{d} \leq v_{i} \leq \sigma_{d}$} & \multicolumn{2}{c}{$-16 \mathrm{~m} \leq v_{i} \leq 16 \mathrm{~m}$} & \multicolumn{3}{c}{$-1.645 \sigma_{d} \leq v_{i} \leq 1.645 \sigma_{d}$} & \multicolumn{3}{c}{$-3 \sigma_{d} \leq v_{i} \leq 3 \sigma_{d}$} & $N$ \\
& $n$ & $\%$ & $n$ & $\%$ & $n$ & $\%$ & $n$ & $\%$ & \\
\hline SRTM3F & 374 & $\mathbf{8 4}$ & 383 & $\mathbf{8 6}$ & 407 & $\mathbf{9 2}$ & 433 & 98 & 443 \\
SRTM33 & 283 & 82 & 289 & 83 & 315 & 91 & 341 & 98 & 347 \\
SRTM0505 & 284 & 82 & 290 & 82 & 316 & 91 & 338 & 97 & 347 \\
LDEM & 265 & $\mathbf{7 6}$ & 276 & 80 & 326 & 94 & 342 & $\mathbf{9 9}$ & 347 \\
LDEM33 & 270 & 78 & 270 & $\mathbf{7 8}$ & 323 & 93 & 342 & 99 & 347 \\
SRTM30 & 363 & 82 & $419^{+}$ & 95 & 396 & $\mathbf{8 9}$ & 430 & 97 & 443 \\
GTOPO30 & 337 & $\mathbf{7 6}$ & $369^{+}$ & 84 & 399 & 90 & 422 & $\mathbf{9 5}$ & 443 \\
\hline
\end{tabular}

$-\sigma_{d} \leq v_{i} \leq \sigma_{d}$,

$-16 \mathrm{~m} \leq v_{i} \leq 16 \mathrm{~m}$,

- $1.645 \sigma_{d} \leq v_{i} \leq 1.645 \sigma_{d}$,

$-3 \sigma_{d} \leq v_{i} \leq 3 \sigma_{d}$.

The number of samples within the $-\sigma_{d} \leq v_{i} \leq \sigma_{d}$ error margin exceeds the limits of normal distributed samples of $68 \%$ significantly. However, none of the DEMs in Table 4 meets the a priori defined $90 \%$ confidence level of $16 \mathrm{~m}$ (see Sect. 3.1). The residuals of all DEMs are within the $90 \%$ confidence interval, if Eqs. (6) or (7) is applied.

For analyzing the influence of outliers we computed the statistics according to Eq. (4), with which we have eliminated outliers before. In Tables 5-7 the statistics for the different error margins are shown.

SRTM3F generally has the smallest standard deviation. For the accuracy investigation of SRTM3F, 443 GCPs are available compared to 347 for SRTM33 and LDEM. Each of these additional 96 GCPs are located at altitudes between $100 \mathrm{~m}$ and $1000 \mathrm{~m}$, the elevation range where SRTM data fit within the $90 \%$ confidence level of $16 \mathrm{~m}$ with GCPs heights.

After SRTM3F, standard deviation of LDEM has the smallest value (Tables 5-7).

Depending on the number of deleted outliers, interpolation of SRTM33 on a finer grid of $0.5 \times 0.5^{\prime \prime}$ decreases the standard deviation $\sigma_{d}$ up to $6.6 \%$; averaging of LDEM on a $3 \times 3^{\prime \prime}$ grid increases $\sigma_{d}$ by more than $25 \%$ (Tables 5-7).

In Figs. 5e and $5 f$ the residuals $v_{i}$ of LDEM and SRTM33 are plotted over GCP heights $h_{\mathrm{GCP}}$. The plot exhibits two important features:

- LDEM residuals are $<0$ in the range between $100 \mathrm{~m} \leq h_{\mathrm{GCP}} \leq 500 \mathrm{~m}$. Above $500 \mathrm{~m}$ the dispersion of the residuals is low. There, LDEM heights are larger than GCP heights.

- SRTM33 residuals show small variations between $100 \mathrm{~m} \leq h_{\mathrm{GCP}} \leq 1000 \mathrm{~m}$. The dispersion increases with increasing $h_{\mathrm{GCP}}$.
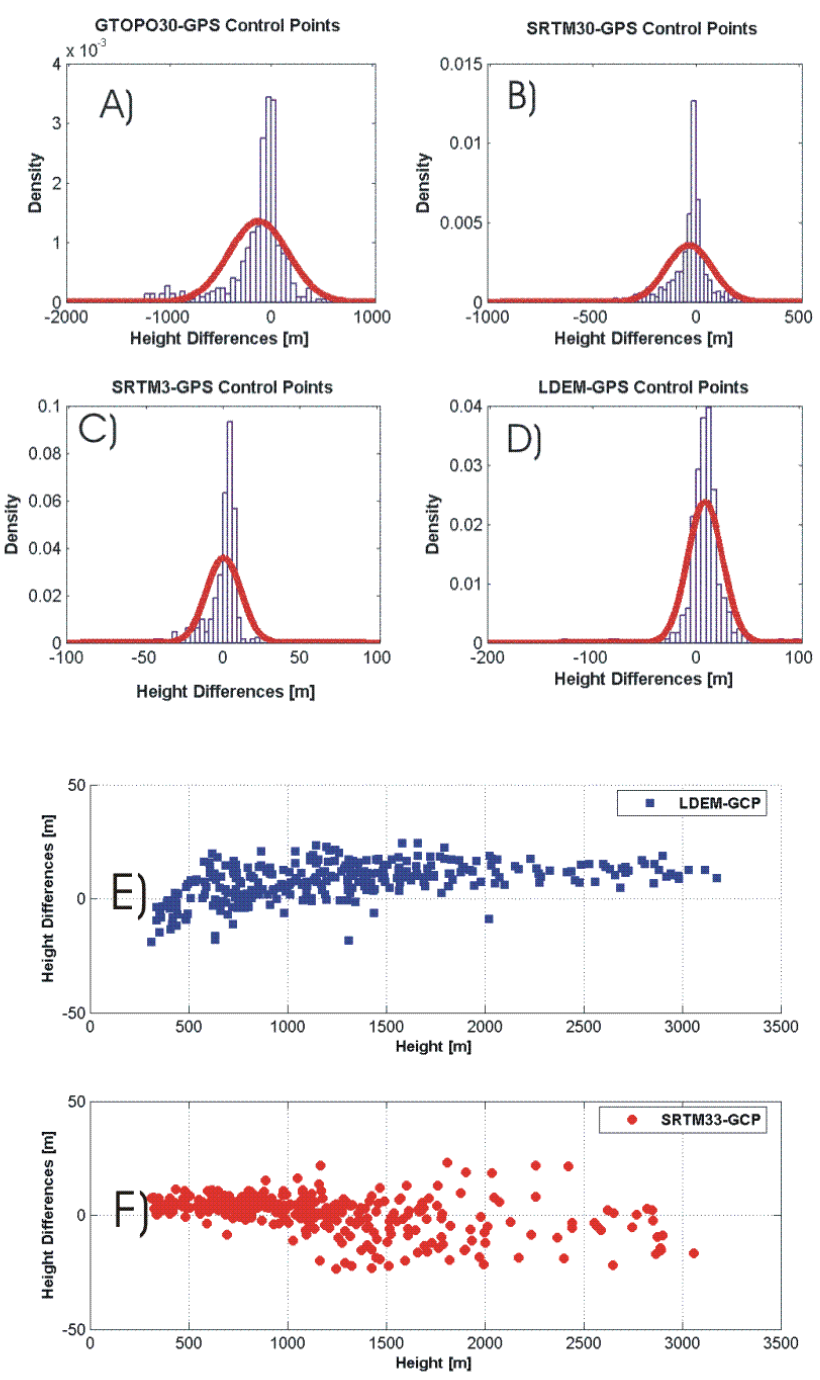

Fig. 5. Histograms and scatter plots of height differences $d_{i}$ : (a) GTOPO30-GCP; (b) SRTM30-GCP; (c) SRTM-3F-GCP; (d) LDEM-GCP; red curve is the normal distribution; (e) scatter plot of LDEM height differences $d_{i}$ over GCP heights $h_{\mathrm{GCP}}$; (f) scatter plot of SRTM33 height differences $d_{i}$ over $h_{\mathrm{GCP}}$. 
Table 5. Statistics for $90 \%$ confidence level: outliers $\left|v_{i}\right| \geq 3 \times \sigma_{d}$ are not considered; $n=$ number of analyzed $v_{i}$; iqr=interquartile range. Extreme values are marked by bold numbers.

\begin{tabular}{|c|c|c|c|c|c|c|c|c|}
\hline DEM & $n$ & bias $h_{\mathrm{off}}(\mathrm{m})$ & median $(\mathrm{m})$ & standard deviation $\sigma_{d}(\mathrm{~m})$ & skewness $\gamma_{d}$ & kurtosis $\kappa_{d}$ & range $(\mathrm{m})$ & $i q r(\mathrm{~m})$ \\
\hline SRTM3F & 433 & 0.4 & 3.1 & 10.5 & -1.3 & 6.0 & 76 & 7.6 \\
\hline SRTM33 & 341 & -41.1 & 2.3 & 12.3 & -1.2 & 5.1 & 81 & 10.8 \\
\hline SRTM0505 & 338 & -0.7 & 2.6 & 11.5 & -1.0 & 4.7 & 74 & 10.9 \\
\hline LDEM & 342 & 8.7 & 9.4 & 9.6 & -0.1 & 5.1 & 77 & 10.7 \\
\hline LDEM33 & 342 & 4.7 & 5.3 & 12.8 & -0.2 & 4.0 & 88 & 15.3 \\
\hline SRTM30 & 430 & -7.7 & 1.0 & 54.2 & -0.7 & 6.1 & 395 & 32.5 \\
\hline GTOPO30 & 422 & -61.4 & -27.8 & 170.5 & -1.4 & 6.4 & 1197 & 150.3 \\
\hline
\end{tabular}

Table 6. Statistics for $90 \%$ confidence level: outliers $\left|v_{i}\right| \geq 1.645 \times \sigma_{d}$ are not considered; $n=$ number of analyzed $v_{i}$; iq $r=$ interquartile range. Extreme values are marked by bold numbers.

\begin{tabular}{lcccccccc}
\hline DEM & $n$ & bias $h_{\text {off }}(\mathrm{m})$ & median $(\mathrm{m})$ & standard deviation $\sigma_{d}(\mathrm{~m})$ & skewness $\gamma_{d}$ & kurtosis $\kappa_{d}$ & range $(\mathrm{m})$ & $i q r(\mathrm{~m})$ \\
\hline SRTM3F & $\mathbf{4 0 7}$ & 1.8 & 3.3 & $\mathbf{7 . 4}$ & $-\mathbf{1 . 0}$ & $\mathbf{4 . 6}$ & $\mathbf{4 4}$ \\
SRTM33 & $\mathbf{3 1 5}$ & 0.9 & 2.9 & 8.4 & -0.8 & 3.8 & 47 \\
SRTM0505 & 316 & $\mathbf{0 . 6}$ & 2.8 & 8.4 & $-\mathbf{1 . 0}$ & 3.8 & 46 \\
LDEM & 326 & 7.7 & 9.1 & $\mathbf{8 . 0}$ & -0.7 & 3.5 & 43 & 10.5 \\
LDEM33 & 323 & 4.1 & 5.1 & 33.8 & -0.4 & $\mathbf{3 . 0}$ & 51 \\
SRTM30 & 396 & -1.9 & $\mathbf{1 . 9}$ & $\mathbf{1 1 9 . 3}$ & -0.3 & 4.5 & 215 & 28.3 \\
GTOPO30 & 399 & $\mathbf{- 3 4 . 4}$ & $\mathbf{- 2 2 . 9}$ & & & $\mathbf{0 . 3}$ & $\mathbf{7 5 4}$ & $\mathbf{1 2 8}$ \\
\hline
\end{tabular}

Table 7. Statistics: residuals $\left|v_{i}\right|>16 \mathrm{~m}$ are not considered; $n=$ number of analyzed $v_{i}$, iqr=interquartile range. Extreme values are marked by bold numbers.

\begin{tabular}{lcccccccc}
\hline DEM & $n$ & bias $h_{\text {off }}(\mathrm{m})$ & median $(\mathrm{m})$ & standard deviation $\sigma_{d}(\mathrm{~m})$ & skewness $\gamma_{d}$ & kurtosis $\kappa_{d}$ & range $(\mathrm{m})$ & $i q r(\mathrm{~m})$ \\
\hline SRTM3F & 383 & 2.4 & 3.4 & $\mathbf{5 . 7}$ & 6.3 & $-\mathbf{1 . 0}$ & 4.1 & 31 \\
SRTM33 & 289 & 1.8 & 3.1 & 6.1 & -0.8 & 3.3 & 31 \\
SRTM0505 & 290 & 2.0 & 3.2 & 6.6 & -0.8 & 3.1 & $\mathbf{5 . 7}$ \\
LDEM & 276 & $\mathbf{6 . 3}$ & $\mathbf{7 . 6}$ & 3.8 & -0.3 & 3.0 & 31 & $\mathbf{3 0}$ \\
LDEM33 & $\mathbf{2 7 0}$ & 3.1 & 3.4 & 46.7 & -0.7 & $\mathbf{5 . 8}$ & 31 & 11.9 \\
SRTM30 & $\mathbf{4 1 9}$ & -5.7 & 1.1 & 75.2 & $\mathbf{0 . 0 7}$ & 2.5 & $\mathbf{3 1 9}$ & $\mathbf{9 8 . 4}$ \\
GTOPO30 & 337 & $\mathbf{- 1 3 . 9}$ & $\mathbf{- 9 . 6}$ & &
\end{tabular}

We have binned the residuals $v_{i}$ in different classes depending on height $h_{\mathrm{GCP}}$, aspect $A_{\mathrm{GCP}}$ and slope $\alpha_{\mathrm{GCP}}$ at the GCP locations in order to investigate the regression of biases and standard deviations on GCP heights, aspects and slopes. Number of samples/class is shown in Table 8.

In Figs. 6-8 class biases and class standard deviations are plotted for the different DEMs.

The SRTM-class biases and standard deviations change nonlinearly with height $h_{\mathrm{GCP}}$ (Fig. 6): Up to $1000 \mathrm{~m}$ a.s.1. class biases are $>0 \mathrm{~m}$; the dispersions of the residuals are small. The standard deviations confirm that the data are quite well within the $90 \%$ confidence interval of $16 \mathrm{~m}$. Above $1000 \mathrm{~m}$ a.s.l. the SRTM-biases become $<0 \mathrm{~m}$. Standard deviations increase significantly.
Similar behavior shows the plot of biases and standard deviations over the slope $\alpha$ (Fig. 6). For slopes between $0^{\circ}<\alpha<10^{\circ}$ we find biases $\geq 0 \mathrm{~m}$ and standard deviations between 6 and $10 \mathrm{~m}$. For slopes $\alpha>10^{\circ}$ the biases are $<0 \mathrm{~m}$ and the standard deviations increase up to $35 \mathrm{~m}$.

There also seems to be a correlation between aspect $\mathrm{A}$ and the class biases $h_{\text {off }}$. Biases $h_{\text {off reach at aspects between }}$ $100^{\circ}$ and $150^{\circ}$ a maximum.

The photogrammetric LDEM exhibits homogenous accuracy (red lines in Fig. 7). Standard deviation $\sigma_{d}$ decreases with increasing altitude in agreement with Eq. (2). Differences between the particular class biases are tested as not statistically significant at the $95 \%$ confidence level. Statistically significant dependency of LDEM biases from aspect A and slope $\alpha$ is also not found. 

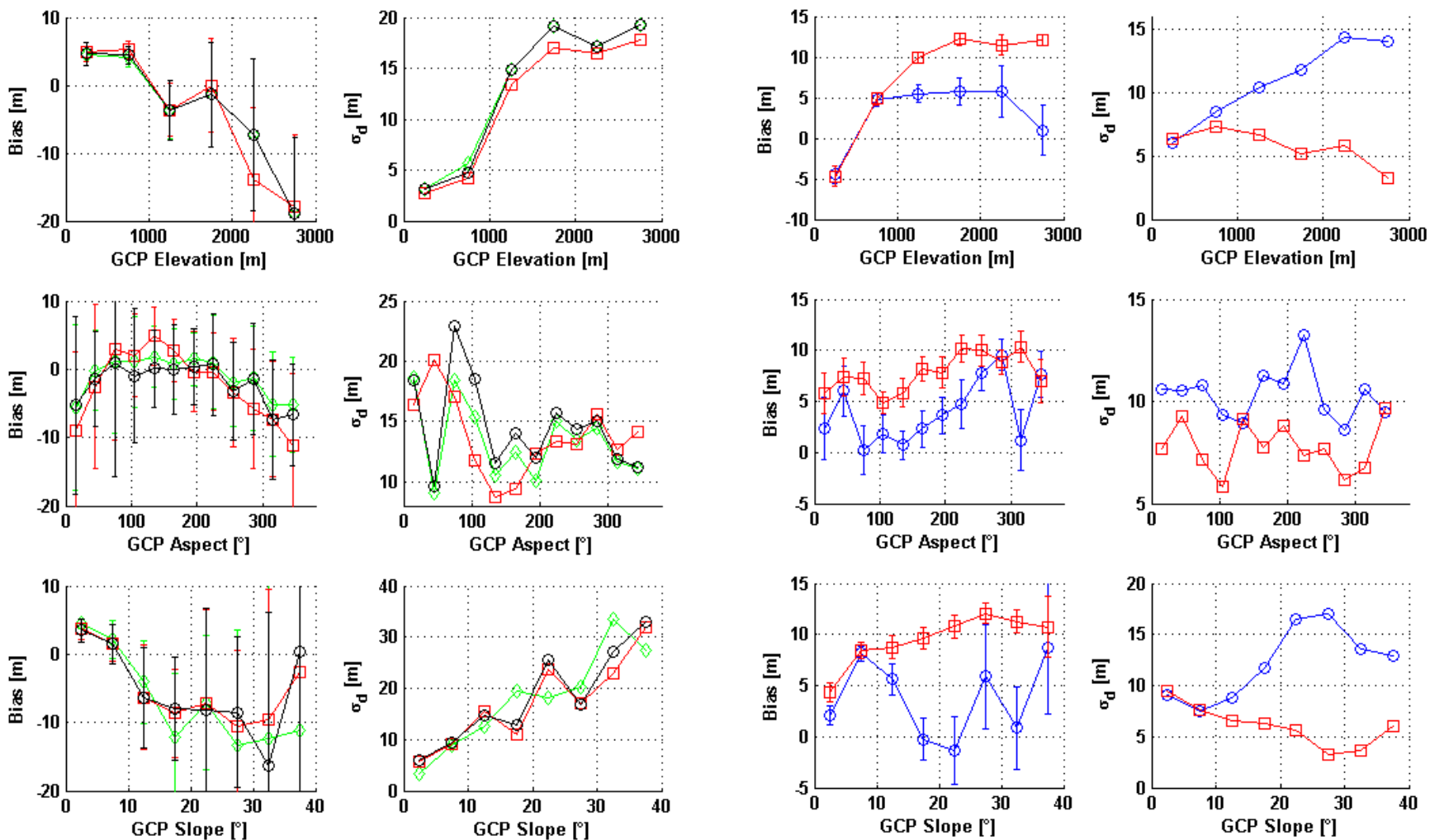

Fig. 6. Class biases $\mathrm{h}_{o f f}$ and standard deviations $\sigma_{d}$ of SRTM3F, SRTM33 and SRTM0505 heights plotted over GCP elevations, aspects and slopes. Error bars of class biases are $3 \sigma$ error bars. Red lines=SRTM0505 biases and standard deviations; green lines=SRTM 3F biases and standard deviations; blue lines=SRTM33 biases and standard deviations.

Class biases of LDEM33 (blue lines in Fig. 7) differ for heights $h_{\mathrm{GCP}}>1000 \mathrm{~m}$ from LDEM-class biases. Class standard deviations of the LDEM $33 v_{i}$ increase with $h_{\mathrm{GCP}}$. They are generally larger than LDEM class standard deviations.

Figure 8 demonstrates that class biases of GTOPO30 and SRTM30 become smaller with increasing $h_{\mathrm{GPC}}$ and slope $\alpha_{\mathrm{GCP}}$; however, the class standard deviations increase. SRTM30 heights fit $h_{\mathrm{GCP}}$ much better than GTOPO30 heights even at high altitudes. Biases of GTOPO30 heights are strongly dependent on aspect $A_{\mathrm{GCP}}$.

The locations of GCPs whose residuals $v_{i}$ exceed the error bound $-16 \mathrm{~m} \leq v_{i} \leq 16 \mathrm{~m}$ are plotted in Fig. 9. For LDEM most of these points are located on the western slopes of Merapi, whereas the outliers for SRTM-DEMs are distributed more randomly on the eastern slopes of Merbabu and Merapi.

\subsection{Relative accuracy of DEMs}

In this section we estimate the relative accuracy between SRTM DEMs and LDEM as well as between SRTM30 and GTOPO30. The aim is to identify areas with systematic differences between the particular DEMs. The large number of samples (cells) allows the estimation of reliable statis-
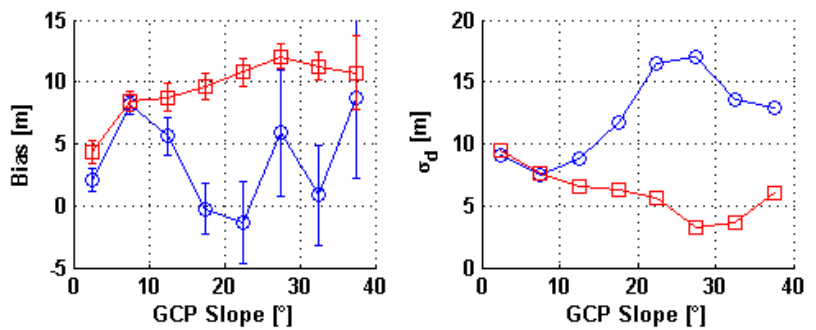

Fig. 7. Class biases $\mathrm{h}_{o f f}$ and standard deviations $\sigma_{d}$ of LDEM and LDEM33 plotted over GCP heights, aspects and slopes. Error bars of class biases are $3 \sigma$ error bars. Red lines=LDEM biases and standard deviations; blue lines=LDEM33 biases and standard deviations.

tics. For this study we use all LDEM-models and GTOPO30 as reference models ( $\left.h_{\mathrm{DEM} 2}, A_{\mathrm{DEM} 2}, \alpha_{\mathrm{DEM} 2}\right)$ according to Eq. (5).

\subsubsection{Comparison between SRTM3 and LDEM}

Comparisons were carried out in 2 ways:

- comparison of DEM heights,

- comparison of aspects and slopes.

Two pairs of DEMs were compared:

- SRTM33 - LDEM33,

- SRTM0505 - LDEM.

Results are given in Table 9. The biases $h_{\text {off }}$ between SRTM33 and LDEM33 as well as SRTM0505 and LDEM correspond well with the mean geoid height of $-25.7 \mathrm{~m}$. Again the residuals $v_{i}$ are not distributed normally, since skewness $\gamma_{d}$ is $\neq 0$. Standard deviations $\sigma_{d}$ vary between $12.5 \mathrm{~m}$ and $13.9 \mathrm{~m}$ and are smaller for the coarse grid DEMs (SRTM33 and LDEM33). Relative accuracy is of the same order as the absolute accuracy shown in Table 5. 
Table 8. Binning of residuals $v_{i}$ of investigated DEMs dependent on height, aspect and slope at GCP locations; numbers are the samples/class.

\begin{tabular}{|c|c|c|c|c|c|c|c|}
\hline Classification & SRTM 3F & SRTM 33 & SRTM 0505 & LDEM33 & LDEM & SRTM 30 & GTOPO 30 \\
\hline \multicolumn{8}{|l|}{ Height $h_{\mathrm{GCP}}$} \\
\hline$h \leq 500$ & 107 & 32 & 32 & 29 & 29 & 107 & 107 \\
\hline $500<h \leq 1000$ & 127 & 106 & 106 & 101 & 99 & 127 & 127 \\
\hline $1000<\bar{h} \leq 1500$ & 107 & 107 & 107 & 103 & 101 & 107 & 107 \\
\hline $1500<h \leq 2000$ & 55 & 55 & 55 & 48 & 49 & 55 & 55 \\
\hline $2000<h \leq 2500$ & 21 & 21 & 21 & 21 & 23 & 21 & 21 \\
\hline $2500<h$ & 26 & 26 & 26 & 21 & 25 & 26 & 26 \\
\hline \multicolumn{8}{|l|}{ Aspect $A_{\mathrm{GCP}}$} \\
\hline $0^{\circ}<A \leq 30^{\circ}$ & 21 & 18 & 18 & 12 & 15 & 12 & 12 \\
\hline $30^{\circ}<\bar{A} \leq 60^{\circ}$ & 21 & 17 & 25 & 19 & 24 & 20 & 20 \\
\hline $60^{\circ}<A \leq 90^{\circ}$ & 27 & 17 & 15 & 20 & 19 & 48 & 48 \\
\hline $90^{\circ}<A \leq 120^{\circ}$ & 48 & 32 & 33 & 25 & 28 & 86 & 86 \\
\hline $120^{\circ}<\bar{A} \leq 150^{\circ}$ & 52 & 38 & 37 & 43 & 46 & 52 & 52 \\
\hline $150^{\circ}<A \leq 180^{\circ}$ & 53 & 41 & 38 & 38 & 42 & 61 & 61 \\
\hline $180^{\circ}<A \leq 210^{\circ}$ & 61 & 41 & 40 & 38 & 33 & 39 & 39 \\
\hline $210^{\circ}<A \leq 240^{\circ}$ & 44 & 40 & 51 & 32 & 30 & 44 & 44 \\
\hline $240^{\circ}<A \leq 270^{\circ}$ & 40 & 36 & 24 & 31 & 24 & 46 & 46 \\
\hline $270^{\circ}<A \leq 300^{\circ}$ & 32 & 30 & 29 & 34 & 25 & 15 & 15 \\
\hline $300^{\circ}<A \leq 330^{\circ}$ & 21 & 17 & 20 & 13 & 20 & 10 & 10 \\
\hline $330^{\circ}<A \leq 360^{\circ}$ & 23 & 20 & 16 & 18 & 20 & 10 & 10 \\
\hline \multicolumn{8}{|l|}{ Slope $\alpha_{\mathrm{GCP}}$} \\
\hline$\alpha \leq 5^{\circ}$ & 209 & 114 & 114 & 100 & 100 & 225 & 225 \\
\hline $5^{\circ}<\alpha \leq 10^{\circ}$ & 95 & 101 & 101 & 104 & 104 & 158 & 158 \\
\hline $10^{\circ}<\alpha \leq 15^{\circ}$ & 39 & 37 & 37 & 35 & 35 & 33 & 33 \\
\hline $15^{\circ}<\alpha \leq 20^{\circ}$ & 38 & 26 & 26 & 33 & 33 & 2 & 2 \\
\hline $20^{\circ}<\alpha \leq 25^{\circ}$ & 30 & 27 & 27 & 25 & 25 & 18 & 18 \\
\hline $25^{\circ}<\alpha \leq 30^{\circ}$ & 13 & 21 & 21 & 11 & 11 & 5 & 5 \\
\hline $30^{\circ}<\alpha \leq 35^{\circ}$ & 15 & 13 & 13 & 11 & 11 & 2 & 2 \\
\hline $35^{\circ}<\alpha$ & 4 & 4 & 4 & 4 & 4 & 0 & 0 \\
\hline
\end{tabular}

Table 9. Statistics of height differences $d r ; n$ is the number of samples, $h_{\text {off }}$ the bias, $\sigma_{d r}$ the standard deviation, $\gamma_{d r}$ skewness, $\kappa_{d r}$ the kurtosis and iqr the interquartile range, respectively.

\begin{tabular}{lcccccccc}
\hline DEM & $n$ & $h_{\text {off }}(\mathrm{m})$ & median $(\mathrm{m})$ & $\sigma_{d r}(\mathrm{~m})$ & $\gamma_{d r}$ & $\kappa_{d r}$ & range $(\mathrm{m})$ & $i q r(\mathrm{~m})$ \\
\hline SRTM0505-LDEM & 4347440 & -25.7 & -25.1 & 13.9 & -0.32 & 10.9 & 391 & 17.1 \\
SRTM33-LDEM33 & 120598 & -25.7 & -25.7 & 12.5 & -0.29 & 15.1 & 375 & 16.0 \\
SRTM30-GTOPO30 & 14400 & 6.0 & -6.0 & 82.4 & 1.9 & 18.6 & 1657 & 66.0 \\
\hline
\end{tabular}

Additional information gives the plot of the residuals $v_{i}$ in Fig. 9. The residuals at heights up to $600 \mathrm{~m}$ a.s.1. are $>0 \mathrm{~m}$. They become $<0 \mathrm{~m}$ with elevations $>600 \mathrm{~m}$.

If we assume $16 \mathrm{~m}$ as $90 \%$ confidence level for both DEMs, the $90 \%$ confidence level $c l$ for the residuals $v_{i}$ according to the error propagation law is

$c l=16 * \sqrt{2}=22.6 \mathrm{~m}$

Cells where the residuals $v_{i} \leq-22.6$ and $v_{i} \geq 22.6$ are shown in Fig. 9 as magenta and white areas, respectively. The largest magenta area is located at the western foot of Merapi's slopes. According to the aerial images taken in 1981 and 1982 this area was covered by rain forest. In 1996, when we visited this area for the first time, the forest had been replaced by low shrubbery and grass. Perhaps these residuals reflect the change of vegetation.

White areas are located at the south-eastern and northwestern corners of LDEM33.

Again we binned the residuals in the same way as shown in Table 8 . The class biases are plotted against height $h_{\mathrm{LDEM}}$, 
Table 10. Statistics of aspect differences $d A$ and slope differences $d \alpha . h_{\text {off }}$ is the bias, $\sigma_{d}$ the standard deviation and iqr the interquartile range, respectively.

\begin{tabular}{lcccccc}
\hline DEM & $h_{\text {off }}\left({ }^{\circ}\right)$ & $\operatorname{median}\left({ }^{\circ}\right)$ & $\sigma_{d}\left({ }^{\circ}\right)$ & $\max \left({ }^{\circ}\right)$ & $\min \left({ }^{\circ}\right)$ & $\operatorname{iqr}\left({ }^{\circ}\right)$ \\
\hline Aspect difference $d A\left(^{\circ}\right)$ & & & & & & \\
\hline SRTM0505-LDEM & 0.3 & 0 & 91 &. &. & 60 \\
SRTM33-LDEM33 & -0.1 & 0 & 50.8 &. &. & 1. \\
\hline Slope difference $d \alpha\left(^{\circ}\right)$ & & & & & & \\
\hline SRTM0505-LDEM & -3.9 & -1.7 & 7.4 & 53.0 & -66.8 & 6.8 \\
SRTM33-LDEM33 & -0.3 & -0.2 & 1.9 & 31.2 & -37.8 & 1.5 \\
\hline
\end{tabular}
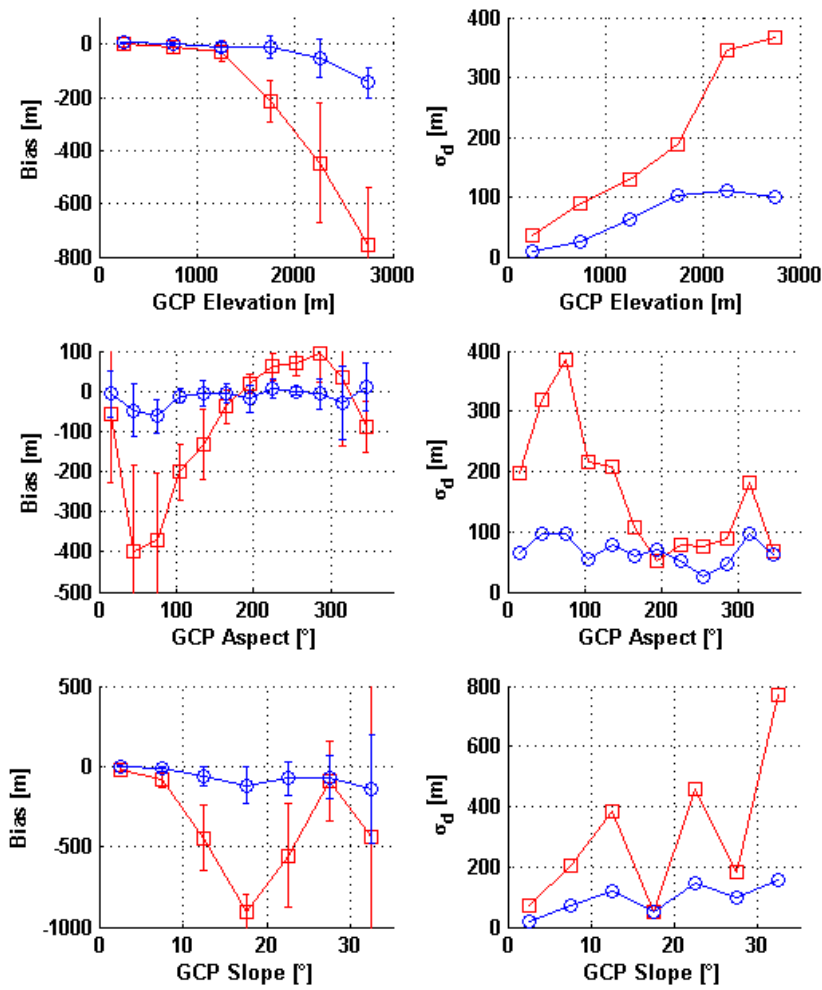

Fig. 8. Class biases $\mathrm{h}_{\text {off }}$ and standard deviations $\sigma_{d}$ of SRTM30 and GTOPO30 heights plotted over GCP heights, aspects and slopes. Error bars of class biases are $3 \sigma$ error bars. Red lines=GTOPO30 biases and standard deviations; blue lines=SRTM30 biases and standard deviations.

aspect $A_{\text {LDEM }}$ and slope $\alpha_{\text {LDEM }}$ (Fig. 10). Absolute values of class biases and standard deviations increase with increasing altitude and slope. Class biases reach maximum values at aspects of $A=135^{\circ}$ and $245^{\circ}$.

\subsubsection{Comparison of aspects and slopes}

Aspect $A$ and slope $\alpha$ are the first derivatives of a DEM. We computed them in order to assess how well topographic details are represented in the different DEMs. In Table 10 we show the basic statistics of the differences $d A_{i}$ and $d \alpha_{i}$ according to Eq. (5).

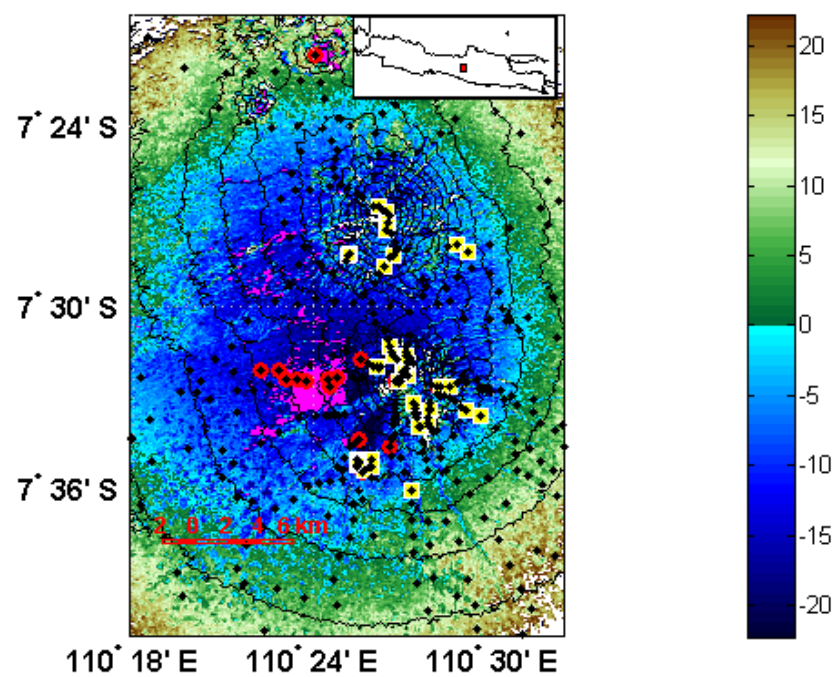

Fig. 9. Residuals $v_{i}=$ SRTM 33 elevations - LDEM 33 elevations; the color bar gives the residuals $v_{i}$ in meters; contour lines show topography; contour line interval is $200 \mathrm{~m}$; magenta areas are regions where residuals $v_{i}<-22.6 \mathrm{~m}$, white areas are regions, where residuals $v_{i}>22.6 \mathrm{~m}$; red circles are GCPs where the residuals between LDEM33 and GCP elevations exceed the $90 \%$ confidence level $( \pm 20.4 \mathrm{~m})$; yellow squares are the GCPs, where the residuals $v_{i}$ between SRTM33 and GCP elevations exceed the 90\% confidence level $( \pm 20.2 \mathrm{~m})$.

There is no significant bias concerning the aspects. Slope biases are small, whereby LDEM slopes are in the mean larger than SRTM slopes. Generally, dispersion parameters such as standard deviation, range and interquartile range iqr for the coarse grid DEMs (SRTM33 and DEM33) are smaller than for the fine grid DEMs. Therefore, the coarse grid DEMs (SRTM33 and DEM33) fit each other better than the fine grid DEMs (LDEM and SRTM0505).

LDEM and DEM33 contain considerably more topographic details than SRTM33 and SRTM0505. As an example, gradients of topography around the summit of Merapi are shown in Fig. 11.

We tested different approaches for automatically extracting topographic structures such as ridges and break lines from the DEMs. The best performance was shown using 

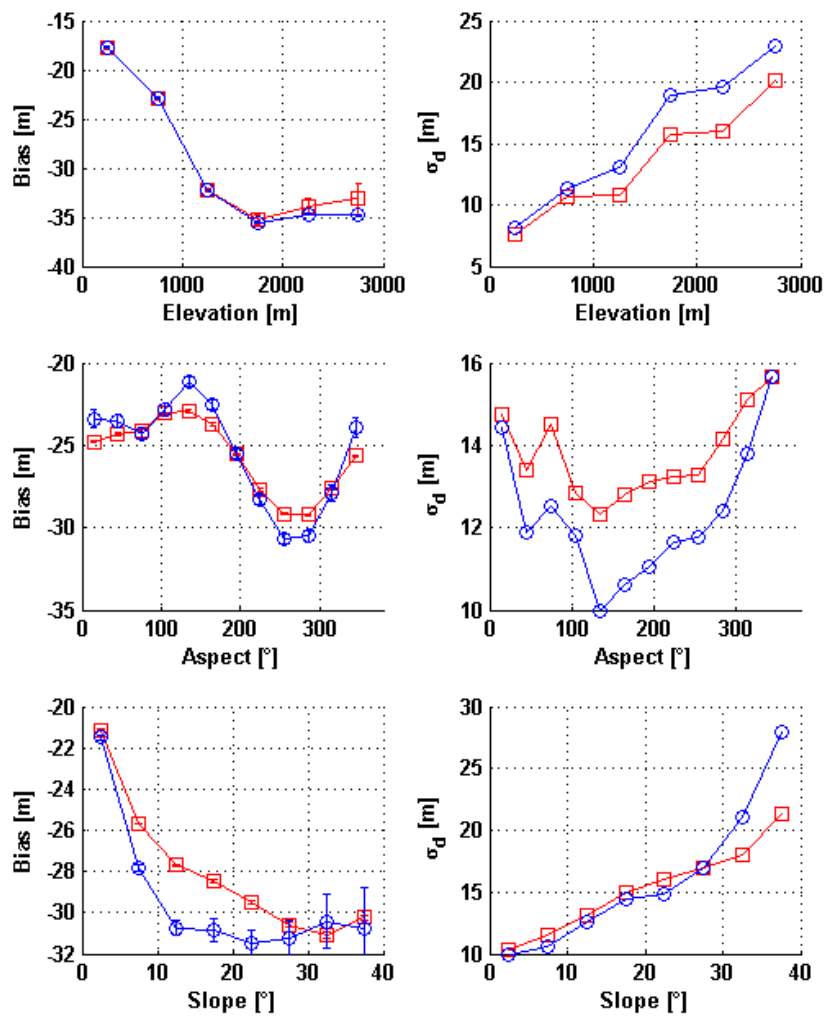

Fig. 10. Class biases $h_{\text {off }}$ and standard deviations $\sigma_{d}$ of SRTM0505 and SRTM33 heights over LDEM and LDEM33 heights, aspects and slopes. Error bars of class biases are $3 \sigma$ error bars. Red lines=SRTM0505 biases and standard deviations; blue lines=SRTM33 biases and standard deviations.

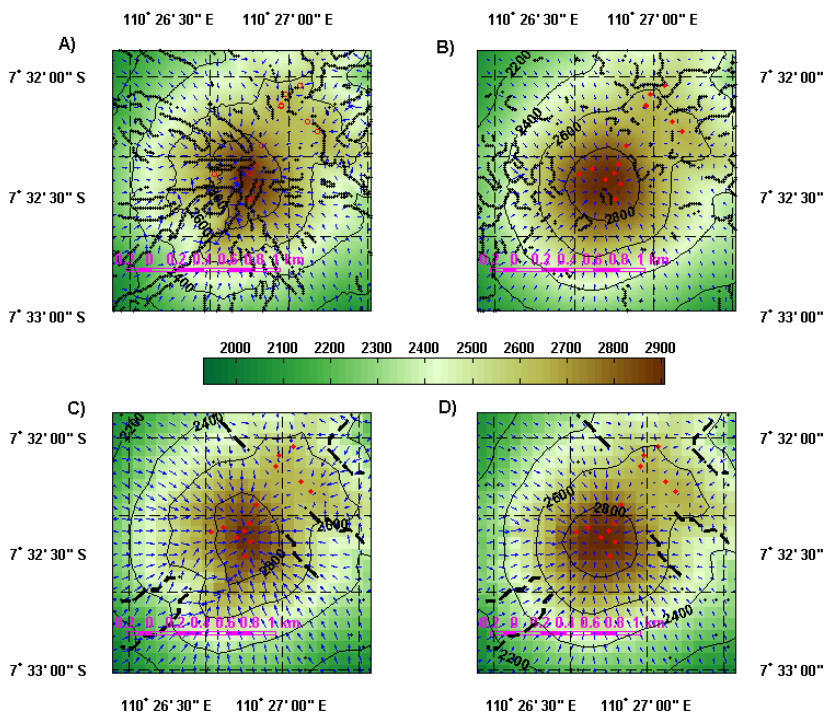

Fig. 11. Topographic details of Merapi summit. Contour line interval is $200 \mathrm{~m}$. Blue arrows show topography's gradients. Dashed black lines are topographic edges and ridges as determined by Canny's algorithm (Canny, 1986). Red markers give the location of the GCPs at the summit. (a) LDEM; (b) SRTM0505; (c) LDEM33; (d) SRTM33.
A)

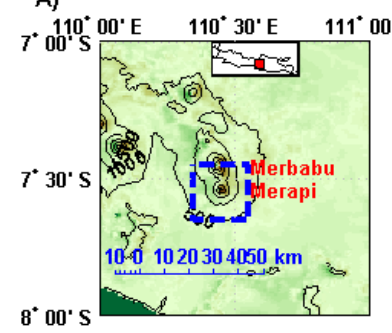

B)

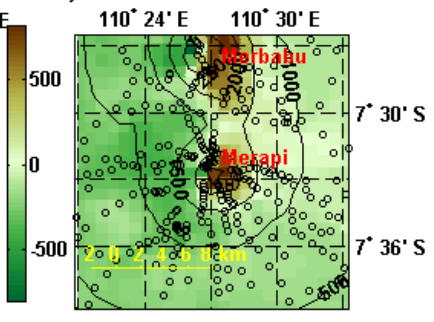

C)

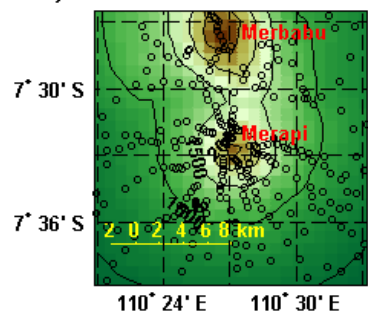

D)

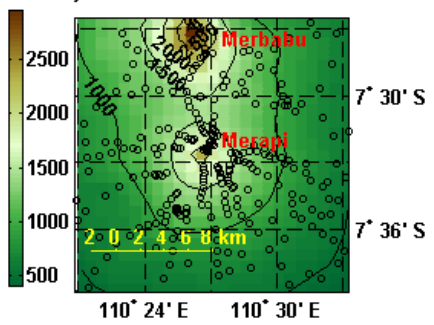

Fig. 12. Height differences between SRTM 30 and GTOPO30 heights. Contour lines give the topography. Contour line interval is $500 \mathrm{~m}$. The circles mark the locations of GCPs. (a) Height differences between SRTM30 and GTOPO30 heights. The blue dashed rectangle gives the range, which is shown in more detail in (b)-(d). (b) Height differences around the summits of Merapi and Merbabu. (c) Detail of SRTM30 DEM around the summits of Merapi and Merbabu. (d) Detail of GTOPO30 DEM around the summits of Merapi and Merbabu.

the algorithm by Canny (1986). With the Canny approach in LDEM many topographic structures are identified. We can check their accuracy using the horizontal positions of the ground control points. Most of the GCPs plotted in Fig. 11 are located very near to ridges and break lines, where they also are in nature (Wrobel et al., 2002).

Ridges and break lines as generated from SRTM33, SRTM0505 and LDEM33 by the Canny algorithm are not correct. Obviously the grid spacing of SRTM33 and LDEM33 is too coarse to render small scale details of the topography.

\subsubsection{SRTM30 - GTOPO30}

The differences $v_{i}$ between SRTM30 and GTOPO30 are unusually large (Table 9, Fig. 12a). The distribution of residuals $v_{i}$ shows some systematic behaviour. The minimum and maximum of residuals $v_{i}$ are found around the summits of Merapi and Merbabu (Fig. 12b). Test computations and plots of the summit areas indicate that after the vertical error the circular horizontal errors exceed the $90 \%$ confidence level of $650 \mathrm{~m}$. In Figs. 12c and 12d the summit areas of SRTM30 and GTOPO30 are plotted together with the GCPs. The summit areas of Merapi and Merbabu of both DEMs do not coincide well with the horizontal position of GCPs, whereby horizontal differences between SRTM30 summit cells and GCPs are significantly smaller. To obtain an optimal fit of SRTM30 and GTOPO30 beneath a vertical bias $h_{\text {off }}$ horizontal offsets 

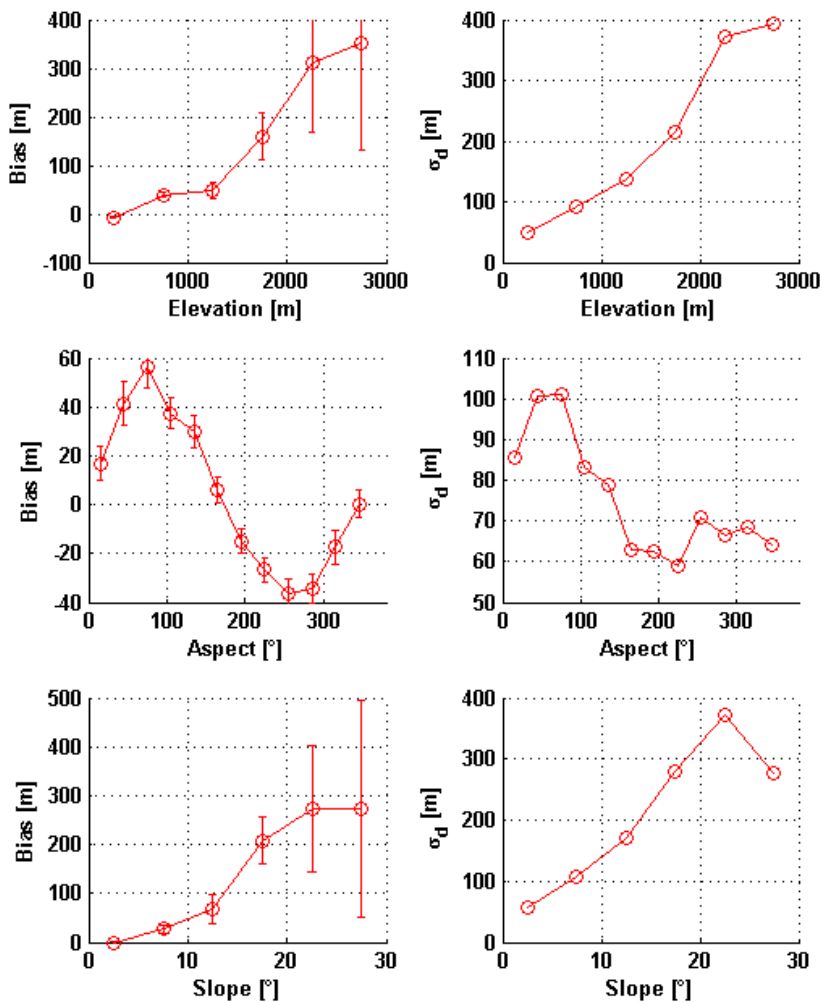

Fig. 13. Class biases $h_{\text {off }}$ and standard deviations $\sigma_{d}$ of SRTM30 heights over GTOPO30 heights, aspects and slopes. Error bars of class biases are $3 \sigma$ error bars.

$x_{o}$ and $y_{o}$ should also be determined with the help of a 3dimensional similarity transformation (Heipke et al., 2002).

Class biases $h_{\text {off }}$ and class standard deviations $\sigma_{d}$ increase with elevations and slopes. Class biases are also dependent on aspects, where the extreme values are found at aspects of $75^{\circ}$ and $255^{\circ}$ (Fig. 13). Primarily the circular errors are responsible for the dependencies of residuals on aspect and the increase of class biases with elevation and slope.

\section{Conclusions}

This study provides a broad range of results on the accuracy of investigated DEMs. Generally we can show that SRTM3 and SRTM30 are a vast improvement on previous global DEM products.

However, the biases and standard deviations of the DEMs analysed are nonlinearly dependent on elevations and slopes.

Through comparison with GCPs we find that standard deviation of SRTM3 DEMs increases with elevation and slope, whereas bias shows nonlinear changes. The specified $90 \%$ confidence level of $16 \mathrm{~m}$ is exceeded when absolute heights are $>1000 \mathrm{~m}$. Up to an elevation of $1000 \mathrm{~m}$ the SRTM data satisfy the $90 \%$ confidence level.

The photogrammetric LDEM data displays accuracy similar to SRTM3. Class biases also change with altitude. However, class standard deviations decrease with elevation.
LDEM data represent more topographic details than SRTM3, e.g. break lines and ridges. This is also true if LDEM data are averaged on the coarser grid size of SRTM3. Averaging decreases accuracy. Interpolation of SRTM3 data on a finer grid possibly decreases standard deviation. However, interpolation cannot improve the topographic details.

The DEMs generated by the SRTM mission are a substantial and very significant step towards detailed accurate global DEMs, especially for far, remote and poorly surveyed regions.

SRTM30 is an excellent replacement of the inhomogeneous GTOPO30, particularly in mountainous regions like the volcanic area around Merapi and Merbabu.

However, SRTM3 does not make the generation of local, high resolution DEMs unnecessary. Such models are only generated by special missions (laser scanning, large scale aerial photogrammetric images, airborne SAR) dedicated to the determination of a high resolution, highly accurate DEM.

Acknowledgements. Research has been partly supported by the German Research Society under project no. GE 381/12 1-4. The authors thank M. Hovenbitzer and F. Guzzetti for their help in improving this study significantly.

Edited by: M. Jaboyedoff

Reviewed by: F. Guzzetti and M. Hovenbitzer

\section{References}

3D Nature: SRTMFILL, http://www.3dnature.com/srtmfill.html, 2003.

Boucher, C., Altamimi, Z., Sillard, P. and Feissel-Vernier, M.: The ITRF2000, IERS Technical Note, 31, Verlag des Bundesamtes für Kartographie und Geodäsie, Frankfurt am Main, 2004.

Canny, J.: A computational approach to edge detection, IEEE Transactions on Pattern Analysis and Machine Intelligence, Vol. PAMI 8, 679-698, 1986.

Danko, D. M.: The digital chart of the world, Geoinfo Systems, 2, 29-36, 1992.

Division, S. M.: GPSurvey Software User's Guide, Sunnyvale, CA 94088-3642, USA, 1995.

Eineder, M.: Problems and solutions for INSAR digital elevation models generation of mountainous terrain, Proceedings of FRINGE Workshop, Frascati, 1-5 December 2003, ESA SP-550, June 2004.

Falorni, G., Teles, V., Vivoni, E. R., Bras, R. L., and Amaratunga, K. S.: Analysis, characterization and effects on hydrogeomorphic modeling of the vertical accuracy of Shuttle Radar Topography Mission digital elevation models, J. Geophys. Res. - Earth Surface, in press, 2005.

Farr, T. G. and Kobrick, M.: Shuttle Radar Topographic Mission produces a wealth of data, EOS, Transactions, American Geophysical Union, 81, 583-585, 2000.

Gamache, M.: Free and low cost datasets for international mountain cartography, http://www.icc.es/workshop/abstracts/ ica_paper_web3.pdf, 2004.

Gerstenecker, C., Heinrich, R., Jentzsch, G., Kracke, D., Läufer, G., Suyanto, I., and Weise, A.: Microgravity at Merapi volcano: Results of the first two campaigns, in Decade Volcanoes under Investigation, edited by: Zschau, J. and Westerhaus, M., 
1. Merapi-Galeras Workshop Potsdam, 25 June 1998, Deutsche Geophysikalische Gesellschaft, Sonderband III, 1998.

Gesch, D. B., Verdin, K. L., and Greenlee, S. K.: New land surface digital elevation covers the earth, EOS, Transactions, American Geophysical Union, 80, 69-70, 1999.

Götz, C.: Auswertung und Deformationsanalyse von GPSMessungen am Vulkan Merapi auf Java, Indonesien, Diplom Thesis, Institute of Physical Geodesy, Darmstadt University of Technology, 2003.

Hansen, R. F.: Radar Interferometry. Data interpretation and analysis. Kluwer Academic Publishers, Dordrecht, The Netherlands, 2001.

Heipke, C., Koch, A., and Lohmann P.: Analysis of SRTM DTMMethodology and practical results, Swedish Photogrammetric Journal Bildteknik/Image Science, No. 2002:1, April 2002.

Heiskanen, W. A. and Moritz, H.: Physical Geodesy, W. H. Freeman and Co., San Francisco and London, 1967.

Hugentobler, U., Schaer, S., and Fridez, P. (eds.): Bernese GPS software version 4.2, Astronomical Institute, University of Berne, 2001.

Jarvis, A., Rubiano, J., and Cuero, A.: Comparison of SRTM derived DEM vs. topographic map derived DEM in the region of Dapa, http://gisweb.ciat.cgiar.org/sig/download/laboratory_ gis/srtm_vs_topomap.pdf, 2004a.

Jarvis, A., Rubiano, J., Nelson, A., Farrow, A., and Mulligan, M.: Practical use of SRTM data in the tropics - comparisons with digital elevation models generated from cartographic data, International Center for Tropical Agricultura, Working Document, no. $198,2004 b$.

Jentzsch, G., Weise, A., Rey, C., and Gerstenecker, C.: Gravity changes and internal processes: some results obtained from observations at three volcanoes, Pure and Applied Geophysics, 161, 1415-1431, 2004.

Jousset, P.: Structure et Dynamisme du Volcan Merapi, Indonesie, $\mathrm{PhD}$ thesis, Universite VII, IPGP Paris, 1996.

Kocak, G., Büyüksalih, G., and Jacobsen, K.: Analysis of digital elevation models determined by high resolution space images, IntArchPhRS, Band XXXV, Teil B4, 636-641, Istanbul, 2004.

Koch, A. and Heipke, C.: Quality Assessment of Digital Surface Models derived from the Shuttle Radar Topography Mission (SRTM), Proceedings of IGARSS, Sydney, Australia, Supplement CD, 2001.

Kraus, K.: Photogrammetrie, Band 3, Topographische Informationssysteme. Dümmler, Köln, 2000.

Kraus, K.: Photogrammetrie, Band 1, Geometrische Informationen aus Photographien und Laserscanneraufnahmen, 7. Auflage, Walter de Gruyter, Berlin, New York, 2004.

Läufer, G.: Erzeugung hybrider digitaler Höhenmodelle aktiver Vulkane am Beispiel des Merapi, Indonesien, PhD thesis, Darmstadt University of Technology, Aachen, 2003.

Lemoine, F. G., Smith, D. E., Kunz, L., Smith, R., Pavlis, E. C., Pavlis, N. K., Klosko, S. M., Chinn, D. S., Torrence, M. H, Williamson, R. G., Cox, R. G., Rachlin, K. E., Wang, Y. M, Kenyon, S. C., Salman, R., Trimmer, R., Rapp, R. H., and Nerem, R. S.: The development of the NASA GSFC and NIMA joint geopotential model, in: Gravity, Geoid and Marine Geodesy, edited by: Segawa, J., Fujimoto, H., and Okubo, S., International Association of Geodesy Symposia, 117, 461-469, 1997.
Meybeck, M., Green, P., and Vörörmart, C.: A new typology for mountains and other relief classes: An application to global water resources and population distribution, Mountain Research and Development, 21, 34-45, 2001.

Muller, J. P., Morley, J. G., Walker, A. H., Kitmitto, K., Mitchell, K. L., Chugani, K., Smith, A., Barnes, J., Keenan, R., Cross, P. A., Dowman, I. J., and Quarmby, N.: The LANDMAP project for the automated creation and validation of multiresolution orthorectified satellite image products and a 1" DEM of the British isles from ERS tandem SAR interferometry, LANDMAP Special Session, RSS200, Leicester University, http://www.landmap.ac. uk/docs/RSS00_JPM_paperV1.pdf, 2000.

NIMA: Performance specification Digital Terrain Elevation Data (DTED), http://www.nga.mil/ast/fm/acq/890208.pdf, 2000.

Purbawinata, M. A., Ratdomopurbo, A., Sinulingga, I. K., Sumarti, S., and Suharno, I.: Merapi volcano - guide book, Volcanological Survey of Indonesia, Bandung, 1996.

Rosen, P. A., Hensley, S., Joughin, I. R., Li, F. K., Madsen, S. N., Rodriguez, E., and Goldstein, R. M.: Synthetic aperture Radar interferometry, Proceedings IEEE, 88, 333-382, 2000.

Sachs, L.: Angewandte Statistik, 7. Auflage, Springer, Berlin, Heidelberg, New York, 1992.

Sarabandi, K., Brown, C. G., Pierce, L., Zahn, D., and Azadegan, R.: Calibration validation of the SRTM height data for Southeastern Michigan, 2002 IEEE Geoscience and Remote Sensing Symposium (IGARSS'02), Toronto, Canada, Vol. I, 167-169, 2002.

Setiawan, A.: Modeling of gravity changes on Merapi volcano observed between 1997-2000, PhD thesis, Darmstadt University of Technology, 2003.

Smith, B. and Sandwell, D.: Accuracy and resolution of shuttle radar topography mission data, Geophys. Res. Lett., 30, 9, 14671470, 2003.

Snitil, B.: Erstellung eines digitalen Geländemodells aus verschiedenen Datenquellen, Diplom thesis, Institute of Physical Geodesy, Darmstadt University of Technology, 1998.

Tiampo, K., Fernández, J., Jentzsch, G., Charco, M., Tiede, C., Gerstenecker, C., Camacho, A., and Rundle, J.: Elastic - gravitational modelling of geodetic data in active volcanic areas, Recent Research Development in Geophysics, 6, 37-58, 2004.

Tiede, C., Tiampo, K., Fernández, J., and Gerstenecker, C.: Deeper understanding of non-linear geodetic data inversion using quantitative sensitivity analysis, Nonlin. Processes Geophys., 12, 373379, 2005,

SRef-ID: 1607-7946/npg/2005-12-373.

USGS-EROS Data center: GTOPO30 documentation (README file), in: Land Processes Distributed Active Archive Center, http: //edcdaac.usgs.gov/gtopo30/README.asp, 1997.

Van Bemmelen, R. W.: The influence of geological events on human history (an example from central Java), Verh. Kon. Ned. Geol. Mijnb. Genoot. Geol., 16, 20-36, 1956.

Wrobel, B. P., Gerstenecker, C., Läufer, G., Setiawan, A., and Steineck, D.: Photogrammetric-geodetic work for hazard mitigation of the high-risk volcano Merapi on Java (Indonesia), Swedish Photogrammetric Journal Bildteknik/Image Science, No. 2002:1, April, 2002.

Zschau, J., Sukhyar, R., Purbawinata, M. A., Lühr, B., and Westerhaus, M.: Project Merapi, in: Decade Volcanoes under Investigation, edited by: Zschau, J. and Westerhaus, M., 1. MerapiGaleras Workshop Potsdam, 25 June 1998, Deutsche Geophysikalische Gesellschaft, Sonderband III, 1998. 